\title{
Pemeriksaan Formalin Terhadap Ikan Asin Kepala Batu (Pseudocienna Amovensis) dan Dencis (Sardinella Lemuru) di Daerah Medan Helvetia
}

\author{
Tisna Harmawan ${ }^{1 *}$ dan Nunik Fadilla ${ }^{2}$ \\ ${ }^{1}$ Program Studi Kimia Fakultas Teknik Universitas Samudra \\ Jl. Meurandeh, Langsa Aceh 24416, Indonesia \\ ${ }^{2}$ Program Studi Analis Kesehatan Politeknik Kesehatan Dr Rusdi Medan \\ Jl. H Adam Malik No 138-142, Medan Sumatera Utara 20235, Indonesia \\ *Corresponding author: tisna_harmawan@unsam.ac.id
}

\begin{abstract}
ABSTRAK
Formalin merupakan salah satu bahan kimia yang beracun yang digunakan untuk pengawetan jaringan dan dilarang digunakan didalam makanan. Tujuan dari penelitian ini adalah untuk melakukan pemeriksaan formalin didalam ikan asin Kepala Batu (Pseudocienna Amovensis) dan Dencis (Sardinella Lemuru) yang beredar di Medan Helvetia. Metode penelitian ini bersifat eksperimen laboratorium terhadap 5 sampel ikan asin kepala batu dan 5 sampel ikan asin dencis. Pemeriksaan dilakukan dengan uji kromatropat menggunakan asam fosfat serta reaksi asam kromatropat $0,5 \%$ dalam asam sulfat $60 \%$. Hasil penelitian seluruh sampel tidak terjadi perubahan warna ungu maka itu menunjukkan seluruh sampel negatif formalin dan dapat dikonsumsi oleh masyarakat sekitar.
\end{abstract}

Kata Kunci: Formalin, Ikan asin, Uji Kromatropat, Ikan Dencis, dan $\mathrm{H}_{2} \mathrm{SO}_{4}$

\section{PENDAHULUAN}

Produk pangan yang sehat serta aman merupakan syarat yang harus di penuhi oleh bahan pangan. Bahan tambahan pangan adalah bahan yang ditambahkan dengan sengaja ke dalam makanan dalam jumlah kecil, dengan tujuan untuk memperbaiki penampakan, cita rasa, tekstur, flavor, dan memperpanjang daya simpan [1].

Keamanan pangan ditentukan oleh ada tidaknya komponen yang berbahaya baik secara fisik maupun kimia dan mikrobiologi. Dalam PerMenKes RI No.1168MenKes/PER/X/1999 yang merupakan perubahan dari Peraturan Menteri Kesehatan No.722/Menkes/Per/IX/1988 tentang bahan makanan yang dilarang digunakan dalam makanan yang disebutkan salah satunya Asam Borat, Asam Salisilat, Dulsin, Kalium Klorat, Kloramfenikol, Minyak Nabati yang di brominasi, Nitrofurazon, Formalin, Kalium Bromat [2].

Senyawa ini di pasaran dikenal dengan nama formalin. Formaldehyde merupakan bahan tambahan kimia yang efisien, Formalin berupa cairan dalam suhu ruang, tidak bewarna, bau sangat menyengat, mudah larut dalam air atau alcohol. Formalin memiliki kemampuan yang sangat baik ketika mengawetkan makanan, namun walau formalin sangat luar biasa daya pengawetannya, formalin sangat di larang digunakan pada makanan [3].

Didalam industri perikanan, formalin digunakan untuk menghilangkan bakteri yang biasa hidup di sisik ikan. Formalin diketahui sering digunakan dan efektif dalam pengobatan penyakit ikan akibat ektoparasit seperti fluke dan kulit lender, bahan ini juga sangat beracun bagi ikan. Formalin banyak digunakan dalam pengawetan sampel ikan untuk keperluan penelitian dan identifikasi. Untuk pengawetan biasanya digunakan formalin dengan konsentrasi 10\% [4].

Keamanan pangan merupakan hal yang sedang banyak di pelajari karena manusia semakin sadar akan pentingnya sumber makanan dan kandungan yang ada didalam makananya. Seiringnya dengan semakin pesatnya teknik pengolahan pangan, penambahan bahan-bahan aditif pada produk pangan sulit untuk dihindari dan salah satu contohnya formalin. Maraknya penggunaan formalin pada bahan makanan merupakan berita yang sangat mengejutkan pada penghujung tahun 2005 dan awal 2006, walaupun sebenarnya masalah tersebut sudah muncul ke permukaan sejak beberapa tahun lalu [1].

Formalin merupakan salah satu makanan yang dilarang didalam makanan. Bahaya dari formalin bila masuk melalui saluran pencernaan dapat menyebabkan nyeri hebat disertai 
inflamasi ulserasi dan nekrosis membrane mukosa. Selain itu dapat terjadi muntah, hematemesis, diare, hematuria, anuria, vertigo, kejang serta kematian [2]. Akibat masuknya formalin kedalam tubuh bisa akut maupun kronis. Pengaruh formalin terhadap kesehatan yaitu jika terhirup rasa terbakar pada hidung dan tenggorokkan, sukar bernafas. Dan jika terkena kulit dan mata akan terasa gatal.

Ikan asin yang mengandung formalin dapat dilihat dengan ciri - ciri ikan asin yang tidak rusak sampai lebih satu bulan dalam suhu kamar, ikan tampak bersih dan cerah ikan juga tidak berbau khas ikan asin [5].

Pada kecamatan Medan Helvetia terdapat ikan asin yang secara fisik sangat baik, terlihat bersih dan ikannya tidak terlalu berbau khas ikan asin dan terkadang ikan asinnya tidak berbau. Dalam hal penyimpanan, ikan asin dapat di simpan dalam jangka waktu sekitar sebulan dimana seharusnya ikan asin hanya dapat bertahan dalam hitungan minggu. Karena ada kemungkinan pada kecamatan ini masyarakat mengkonsumsi ikan asin sangatlah besar. Sebagai seorang analis ingin menganalisa formalin yang dampaknya sangat berbahaya buat kesehatan manusia yang dapat berdampak kematian apabila di konsumsi dengan berlebihan.

Dari latar belakang diatas peneliti ingin meneliti formalin terhadap ikan asin kepala batu dan ikan asin dencis di Kecamatan Medan Helvetia.

\section{BAHAN DAN METODE}

\section{Bahan}

Asam Fosfat $\left(\mathrm{H}_{3} \mathrm{PO}_{4}\right)_{(\mathrm{p})}$, Aquadest, Asam Sulfat $\left(\mathrm{H}_{2} \mathrm{SO}_{4}\right)_{(\mathrm{p})}$, Asam Kromatropat.

\section{Metode}

Metode penelitian ini merupakan penelitian yang bersifat eksperimen laboratorium dengan melakukan pemeriksaan formalin terhadap ikan asin kepala batu dan ikan asin dencis yang beredar dipasar Sei Sikambing dan dipasar Helvetia Kecamatan Medan Helvetia.

\section{Prosedur Penelitian \\ Uji Kualitatif}

\section{Metode Asam Kromatropat}

1. Ditimbang sebanyak $50 \mathrm{~g}$ sampel dihaluskan dalam lumpang porselin, lalu masukkan kedalam labu destilat yang telah berisi $100 \mathrm{ml}$ aquades.

2. Ditambahkan $5 \mathrm{ml}$ asam fosat $85 \%$.

3. Campuran didestilasi perlahan-lahan hingga diperoleh $20 \mathrm{ml}$ destilat yang ditampung dalam gelas ukur yang telah berisi 1-2 ml aquades.

4. $2 \mathrm{ml}$ destilat dimasukkan kedalam tabung reaksi.

5. Dilarutkan $5 \mathrm{ml}$ asam kromatropat $0,5 \%$ dalam asam sulfat $60 \%$.

6. Lalu panaskan di penangas air hingga mendidih selama 20 menit.

7. Jika berwarna ungu, berarti sampel tersebut mengandung formalin.

8. Dan jika tidak mengandung formalin, maka tidak terjadi perubahan warna pada sampel tersebut.

\section{Uji Kuantitatif}

\section{Metode Polimetri}

1. Sebanyak $2 \mathrm{ml}$ destilat dimasukkan kedalam tabung reaksi.

2. Destilat ditambahkan $25 \mathrm{ml}$ larutan $\mathrm{H}_{2} \mathrm{O}_{2} 3 \%$ dan 50 ml larutan $\mathrm{NaOH} 0,1 \mathrm{~N}$.

3. Panaskan diatas penangas air hingga hampir mendidih.

4. Tambahkan 5 tetes indicator phenolphpthalein hingga berubah warna menjadi merah jambu.

5. Kemudian titrasi dengan larutan $\mathrm{HCl} 0,1 \mathrm{~N}$ hingga warna merah jambu hilang menjadi warna putih.

6. Diperoleh volume pentiter.

7. Buat perhitungan untuk menghitung kadar formalin pada sampel dengan persamaan sebagai berikut:

$$
\mathrm{KF}=\frac{V x N 0.1 \times 0,006183}{\text { Berat Sampel }} \times 100 \%
$$

$$
\text { Keterangan: } \quad \begin{aligned}
\mathrm{V} & =\text { Volume } \\
\mathrm{N} & =\text { Normalitas } \\
\mathrm{KF} & =\text { Kadar Formalin }
\end{aligned}
$$

\section{Metode Spektrofotometer Serapan Atom}

1. Dibuat larutan standart formalin konsentrasi 1000 ppm dengan cara mencampurkan larutan formalin sebanyak 0,25 $\mathrm{ml}$ (Larutan formalin $40 \%$ )

2. Kemudian diencerkan dalam labu takar 100 $\mathrm{ml}$ dengan aquadest sampai tanda batas. 
3. Larutan tersebut kemudian dibuat larutan standart dengan konsentrasi 1, 3, 6, 10, 15, $20,25,30,35,40,50,60,70,80,90,100$, dan $120 \mathrm{ppm}$ dan diencerkan dengan aquadest dalam labu takar $100 \mathrm{ml}$ sampai tanda batas.

4. Larutan pereaksi sebanyak $5 \mathrm{ml}$ dimasukkan ke dalam tabung reaksi, lalu ditambahkan 1 $\mathrm{ml}$ larutan standar formalin (dibuat untuk semua konsentrasi diatas) sambil diaduk.

5. Tabung reaksi dimasukkan kedalam penangas air yang mendidih selama 15 menit, angkat dan dinginkan kemudian masukkan ke dalam kuvet dan ukur absorbansinya dengan spektrofotometrer pada panjang gelombang $560 \mathrm{~nm}$. Plot hubungan antara konsentrasi dengan absorban larutan standart formalin, lalu buat persamaan regresi linier (digunakan untuk menghitung konsentrasi/kadar formalin dalam sampel).

6. Penentuan kadar formalin dalam sampel. Mencampurkan 10 gram sampel dengan $50 \mathrm{ml}$ air dengan cara menggerusnya dalam lumpang. campuran dipindahkan ke dalam labu kjedhal dan diasamkan dengan $\mathrm{H}_{3} \mathrm{PO}_{4}$.

7. Labu kjedhal dihubungkan dengan pendingin dan disuling. Hasil sulingan ditampung dan ditambahkan pereaksi (larutan jenuh asam 1,8-dihidroksinaftalen-3,6-disulfonat $\mathrm{H}_{2} \mathrm{SO}_{4}$ $72 \%$ ) diencerkan dalam labu takar $50 \mathrm{ml}$ sampai tanda batas, kemudian sampel tersebut diukur absorbannya dengan spektrofotometri dan hitung kadar formalinnya.

\section{HASIL DAN PEMBAHASAN}

\section{Pemeriksaan Secara Kualitatif}

Data-data adanya formalin yang terdapat pada ikan asin kepala batu dan ikan asin dencis di daerah Medan Helvetia dapat dilihat pada tabel berikut:
Tabel 1. Hasil Uji Analisis Kualitatif Formalin

\begin{tabular}{|c|l|c|c|}
\hline \multirow{2}{*}{ No. } & \multirow{2}{*}{$\begin{array}{c}\text { Kode } \\
\text { Sampel }\end{array}$} & $\begin{array}{c}|c| \\
(+)\end{array}$ & \\
\cline { 4 - 4 } & Positif & Negatif (-) \\
\hline 1 & Sampel 1 & & - \\
\hline 2 & Sampel 2 & & - \\
\hline 3 & Sampel 3 & & - \\
\hline 4 & Sampel 4 & & - \\
\hline 5 & Sampel 5 & & - \\
\hline 6 & Sampel 6 & & - \\
\hline 7 & Sampel 7 & & - \\
\hline 8 & Sampel 8 & & - \\
\hline 9 & Sampel 9 & & - \\
\hline 10 & Sampel & & - \\
\hline
\end{tabular}

Dari tabel 1. diketahui bahwa dalam ikan asin kepala batu dan ikan asin dencis di daerah Medan Helvetia tidak mengandung formalin.

\section{Pembahasan}

Pada pengamatan ikan secara fisik yaitu untuk kondisi masing-masing ikan asin kepala batu dan ikan asin dencis tidak bisa dibedakan antara ikan asin yang mengandung formalin dengan tidak. Ikan asin yang mengandung formalin dapat dilihat dengan ciri - ciri ikan asin yang tidak mudah rusak sampai lebih satu bulan dalam suhu kamar, ikan tampak bersih dan cerah ikan juga tidak berbau khas ikan asin. Dan sebagian ikan asin yang di analisa memiliki ciri ciri yang sama dengan ikan asin yang mengandung formalin. Ikan asin yang tidak mengandung formalin secara fisik memiliki ciriciri ikan yang dapat disimpan hanya dalam jangka waktu hitungan minggu, ikannya memiliki bau khas ikan asin. Apabila dipasaran ikan asin yang diperdagangkan dapat dilihat ikan di hinggapi lalat, daging ikan yang tidak terlalu keras.

Cara kerja identifikasi adanya formalin yaitu dengan uji kromatopat dengan hasil destilat yang ditambahkan asam kromatropat dalam asam sulfat yang akan terjadi perubahan warna menjadi warna ungu apabila positif mengandung formalin. Apabila tidak terjadi perubahan warna dan tetap jernih maka hasilnya negatif. Dari hasil 
pemeriksaan kualitatif yang telah dilakukan seluruh sampel ikan asin dencis dan kepala batu yang telah diperiksa hasilnya negatif karena tidak terjadi perubahan warna ungu pada sampel ikan asin. Sehingga ikan asin yang beredar di pasar Sei Sikambing dan pasar Helvetia aman untuk dikonsumsi oleh masyarakat. Sehingga untuk pemeriksaan selanjutnya secara kuantitatif tidak dapat dilakukan dikarenakan hasil dari seluruh sampel tidak mengandung formalin.

\section{Dalam}

PerMenKes

RI

No.1168/MenKes/PER/X/1999 yang merupakan perubahan dari Peraturan Menteri Kesehatan No.722/Menkes/Per/IX/1988 tentang bahan makanan yang dilarang digunakan dalam makanan yang disebutkan salah satunya Asam Borat, Asam Salisilat, Dulsin, Kalium Klorat, Kloramfenikol, Minyak Nabati yang di brominasi, Nitrofurazon, Formalin, Kalium Bromat. Ikan segar adalah ikan yang masih mempunyai sifat sama seperti ikan hidup, baik rupa, bau, rasa, maupun teksturnya. Ikan sebagai bahan makanan yang mengandung protein tinggi dan mengandung asam amino esensial yang diperlukan oleh tubuh, disamping itu nilai biologisnya mencapai $90 \%$, dengan jaringan pengikat sedikit sehingga mudah dicerna. Untuk dapat memanfaatkan ikan dengan baik, perlu diketahui karakteristik yang dimiliki, misalnya struktur tubuh ikan, perbandingan ukuran tubuh dan berat, sifat fisik dan kimia, protein, lemak, vitamin, dan senyawa lain yang dikandungnya. Manfaat tersebut diantaranya sebagai sumber energy, membantu pertumbuhan dan pemeliharaan tubuh, memperkuat daya tahan tubuh, juga memperlancar proses fisiologis dalam tubuh [6].

Formalin merupakan cairan jernih yang tidak berwarna atau hampir tidak berwarna dengan bau yang menusuk, uapnya merangsang selaput lendir hidung dan tenggorokan, dan rasa membakar. Formalin akan banyak kita rasakan manfaatnya, misalnya sebagai antibakteri atau pembunuh kuman dalam berbagai jenis keperluan industri, yakni pembersih lantai, kapal, gudang dan pakaian. Didalam industri perikanan, formalin digunakan untuk menghilangkan bakteri yang biasa hidup di sisik ikan. Formalin banyak digunakan dalam pengawetan sampel ikan untuk keperluan penelitian dan identifikasi. Manfaat formalin dalam dunia kesehatan sebagai bahan untuk mengeraskan dan mengawetkan jaringan, senyawa desinfektan, pengawetan mayat, pembasmi serangga.

\section{KESIMPULAN}

Berdasarkan penelitian yang telah dilakukan dapat ditarik kesimpulan sebagai berikut:

1. Berdasarkan penelitian yang telah dilakukan bahwa dari 10 sampel yang ada dipasar Helvetia dan dipasar Sei Sikambing pada uji kualitatif dengan uji kromatropat tidak terjadi perubahan warna ungu dikarenakan sampel tidak mengandung formalin. Seluruh sampel tidak mengandung formalin sehingga sampel aman untuk dikonsumsi masyarakat.

2. Pengaruh formalin jika masuk kedalam tubuh manusia yaitu dapat bersifat karsinogenik (menyebabkan kanker), iritasi lambung, alergi, luka bakar, dan bersifat mutagen (perubahan fungsi sel).

3. Ikan yang fisiknya baik belum tentu mengandung formalin, 10 sampel yang di analisa memiliki fisik yang baik dan mirip dengan ciri-ciri ikan asin mengandung formalin tetapi dari hasil analisa semua sampel negatif.

\section{UCAPAN TERIMA KASIH}

Penulis mengucapkan terima kasih kepada Ketua Yayasan RSU Dr Rusdi Medan atas dukungannya dalam penelitian ini.

\section{REFERENSI}

[1] Widyaningsih, D. T. \& E. S. Murtini. 2006. Alternatif Pengganti Formalin Pada Produk Pangan. Trubus Agrisarana. Surabaya.

[2] Sudjarwo. A, Darmawati \& V, Wahyu Harianti.2013. "Penetapan Kadar Formalin Dalam Ayam Potong Yang Di Pasar Tradisional.

[3] Cahyadi, W. 2012. Analisis dan Aspek Kesehatan Bahan Tambahan Pangan.Edisi Kedua. Bumi Aksara. Jakarta.

[4] Yuliarti, N. 2007. Awas!Bahaya dibalik Lezatnya Makanan. Andi Offset. Yogyakarta.

[5] Adawyah, R. 2008. Pengolahan dan Pengawetan Ikan. Bumi Aksara. Jakarta.

[6] Standart Nasional Indonesia 01-2729.12006. Spesifikasi Persyaratan Ikan Segar. 